\title{
Integration of Cleaner Production and Waste Water Treatment on Tofu Small Industry for Biogas Production using AnSBR Reactor
}

\author{
Suparni Setyowati Rahayu, 2,* ,Budiyono Budiyono, ${ }^{2,3}$, Purwanto Purwanto ${ }^{2,3}$ \\ 1Mechanical Engineering Department, State Polytechnic of Semarang, Indonesia \\ ${ }^{2}$ Doctoral Program of Environmental Science, School of Postgraduate Studies, Diponegoro University, Semarang \\ ${ }^{3}$ Department of Chemical Engineering, Faculty of Engineering, Diponegoro University, Semarang
}

\begin{abstract}
A research on developing a system that integrates clean production and waste water treatment for biogas production in tofu small industry has been conducted. In this research, tofu waste water was turned into biogas using an AnSBR reactor. Mud from the sewage system serves as the inoculums. This research involved: (1) workshop; (2) supervising; (3) technical meeting; (4) network meeting, and (5) technical application. Implementation of clean production integrated with waste water treatment reduced the amount of waste water to be treated in a treatment plant. This means less cost for construction and operation of waste water treatment plants, as inherent limitations associated with such plants like lack of fund, limited area, and technological issues are inevitable. Implementation of clean production prior to waste water treatment reduces pollution figures down to certain levels that limitations in waste water treatment plants can be covered. Results show that biogas in 16 days HRT in an AnSBR reactor contains $\mathrm{CH}_{4}(78.26 \%)$ and $\mathrm{CO}_{2}\left(20.16 \%\right.$ ). Meanwhile, treatments using a conventional bio-digester result in biogas with $72.16 \% \mathrm{CH}_{4}$ and $18.12 \% \mathrm{CO}_{2}$. Hence, biogas efficiency for the AnSBR system is 2.14 times greater than that of a conventional bio-digester.
\end{abstract}

\section{Introduction}

Environmental management can be carried out by prevention and control of pollutants. Environmental management in a cluster of tofu small industry should integrate both aspects. Measures to control pollution usually come with significant cost for equipment and operation that they are often neglected, but these measures become a must when pollutant sources have been identified. On the other hand, measures to prevent pollution are generally both effective and beneficial whenever they are possible to be conducted. Nonetheless, possible effects from pollution are still likely to occur. Therefore, environmental management in a cluster of tofu small industry must be initiated with prevention measures that are integrated with measures to control pollution [1].

A tofu small industry cluster can prevent environmental pollution by, among other things; re-use its waste water as to avoid polluting the water ways. Even though it is not a panacea of all water pollution problems from tofu industry, it helps minimizes those problems. Therefore, the cost and burden for waste water treatment will be reduced.
Environmental management must be carried out sustainably and this is only possible when related measures are easy, cheap, and even beneficial. Hence, measures for environmental management such as the clean production approach is very much applicable in a small industry cluster. A clean production approach that is integrated with pollution control attempts like waste water treatment should be the best approach for environmental management in small industries.

Environmental management has always been identical with being costly and not directly beneficial. This leads to the need for an alternative measure in the form of clean production, which has some benefits [2]. Clean production that is integrated with waste water treatment will reduce the load of waste water to be treated at a treatment plant. In turn, this load reduction reduces the budget for construction and operation of a waste water treatment plant [3]. Some limitations are associated with the ability of a plant to treat waste water, for instance, fund, land acreage, and technology. The practice of clean production prior to waste water treatment should reduce pollution load down to certain levels that those aforementioned limitations can be minimized [4].

Corresponding author: suparnirahayu $@$ yahoo.co.id 
Both physical and chemical treatments are meant to take care of the solids suspended. Meanwhile, anaerobic biological treatment (AnSBR) is an interesting alternative to treat organic compounds in tofu waste industry. Almost all developments in the technology of anaerobic treatment are aimed at containing microorganism in the reactor other than improving the efficiency of biogas formation [5].

Biogas production technology is currently less developed due to slow rate and less efficient production, especially in terms of clean production and waste water treatment in small tofu industry. The problem to be solved by this research is lack of environmental management strategy, and the lagging implementation of clean production in small tofu industry [6].

Based on those considerations, observations and analyses on the effective integration of clean production and waste water treatment in tofu small industry for biogas production were carried out. Further analyses on eco-efficiency of water and energy were also conducted. These are necessary, as achievement and effectivity of waste water treatment in small tofu industry for biogas, and the implementation of clean production, as well as eco-efficiency of energy and water is important information for tofu business people and stakeholders, and especially the policy makers [7].

\section{Experimental Details}

Measures of environmental management involving the small industry can be carried out individually by all business entity or together by a cluster [8]. Individual efforts by a business entity mean that both cost and resources required are from that business entity itself. No communication and cooperation among different business entities are required to do environmental management [9]. This type of effort is usually laden with challenges especially concerning resources, both fund and human resource [10].

On the other hand, a cooperative effort in by a cluster is conducted by either all or some business entities in a cluster. Therefore, both cost and resources required are shouldered by all parties involved. This cluster approach has some advantages compared to the individual one [11].

Integrated approach of clean production and waste water treatment is in essence: a synergy between attempts to improve economic efficiency whilst ensuring environmental well-being (more efficient use of natural resources with less waste and pollution), and efforts for final waste water treatment. These efforts are intertwined and support each other in a cycle of planning, monitoring, and evaluation in a sustainable way [12].

\section{Materials and Methods}

Research activities conducted include five (5) main works: (1) workshop; (2) supervising; (3) technical meeting; (4) network meeting; and (5) technical application.
The Workshop discussed materials on the basic principles of clean production and eco-efficiency, nonproduct output (NPO), inefficient production process, identification of sources for NPO, and ways to calculate NPO cost.

The Supervising is meant to train small industries to formulate their own NPO flow chart, calculate NPO cost, and identify NPO priority based on predicted NPO cost.

The Technical Meeting was aimed at informing the activities of the working team in each cluster and taking input or suggestion from the other clusters, for the improvement and success of activities in each cluster.

The Networking Meeting was directed at informing and synergizing activities that have been and will be done by stakeholders and local government units.

The Technical Application dealt with applying processes in the AnSBR system that consist of five stages; filling, reacting, decanting/drawing, and stabilization/idling. Cycle time for the AnSBR system is around 3 - 24 hours, depending on the characteristics and purposes of treatment. AnSBR system can be modified to accommodate carbon oxidation, nitrification, denitrification, and phosphor elimination. Prior to operation, AnSBR system underwent flushing using 95.95\% nitrogen (Industrial grade) for 30 minutes to get rid of oxygen [13].

Experiment was carried out using AnSBR reactor that is filled with $20 \%$ ditch mud, while the conventional digester contains yoghurt plastic bottles and bamboo plaid for bacteria proliferation. HRT treatment was done for 10, 20, 30, and 40 days. AnSBR operated in five stages of filling $(25 \%)$, reacting $(35 \%)$, precipitation $(20 \%)$, decanting $(15 \%)$, and stabilizing $(5 \%)$, of cycle operation. These processes are conducted every day for 12 hours each [14].

\section{Results and Discussion}

An integrated approach is possible when the whole process of planning for clean production and waste water treatment are carried out, and each is taken into proper consideration, and each process also provide feedback for each other [15]. Implementation of clean production that was integrated with waste water treatment was capable of reducing the load of waste to be treated in the plant. In turn, this load reduction reduced the cost of construction and operation of a waste water treatment plant. Some limitations are associated with the ability of a plant to treat waste water, for instance, fund, land, and technology. The practice of Clean Production prior to waste water treatment could reduce pollution load down to certain levels that those aforementioned limitations can be minimized [16].

During the stage of technical application, research was run for 24 days to produce biogas that was then stored in a storing tank. Biogas was measured for each HRT, starting at HRT 2 (day 2), up to HRT 24 (day 24). On the 10th day, $5815 \mathrm{~mL}$ of biogas was obtained, and this figure kept on growing through day 24. This research tried to figure out and compare the amount of 
biogas produced using AnSBR system, and the conventional bio-digester.

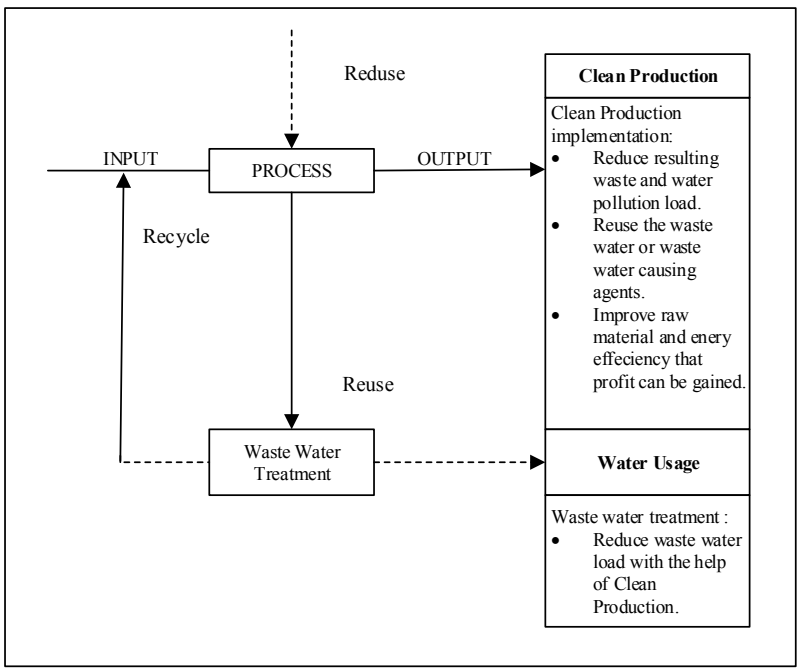

Fig. 1. Clean production that is integrated with waste water treatment.

It is also targeted at finding out the effect of HRT holding time on AnSBR system operated by batches to produce biogas. AnSBR that is operated using tofu waste water and ditch mud as input involving stages of filling, reacting, precipitation, decanting, and stabilization is known as an energy-independent AnSBR, whereas AnSBR that only operates using waste water is called a bio-digester. In this system, microbes are proliferated using bamboo plaid and yoghurt plastic bottles inside it. The effect of HRT on biogas production biogas production was analyzed by setting HRT for the 10th, 20th, 30th, and 40th day. The ratio of input between tofu waste water and ditch much is 5: 1 . The AnSBR was operated at a temperature and a maximum mud concentration of $30{ }^{\circ} \mathrm{C}$ and $20 \%$, respectively. Results of analyzes on the effect of HRT on biogas production are given in Table 1.

Table 1. The effect of HRT on the production of biogas.

\begin{tabular}{ccc}
\hline \multirow{2}{*}{ HRT (day) } & \multicolumn{2}{c}{ Biogas Production (mL) } \\
\cline { 2 - 3 } & AnSBR & $\begin{array}{c}\text { Conventional } \\
\text { Bio-digester }\end{array}$ \\
\hline 10 & 5720 & 1845 \\
20 & 12435 & 5374 \\
30 & 12972 & 6577 \\
40 & 13625 & 7116 \\
\hline
\end{tabular}

Figure 2 shows that high HRT yields high biogas as well. On HRT 10, 20, 30, and 40, AnSBR system had biogas output of $5720,12435,12972$, and $13625 \mathrm{~mL}$, respectively. Meanwhile, the conventional digester produced biogas output of $1845,5374,6577$, and 7116 $\mathrm{mL}$, on the same HRT respectively. On average, the ratio of biogas production between AnSBR reactor and conventional bio-digester is $44752 \mathrm{~mL}$ against $7116 \mathrm{~mL}$. Hence, AnSBR reactor produces 2.14 times more biogas than conventional bio-digester.

During the running period, characteristics of biogas were monitored to the 16th day. This examination included contents of $\mathrm{CH}_{4}, \mathrm{CO}_{2}$, and its heat value. Results show that $\mathrm{CH}_{4}$ content in the biogas was 78.26 $\%$, while the $\mathrm{CO}_{2}$ content was $20.16 \%$.

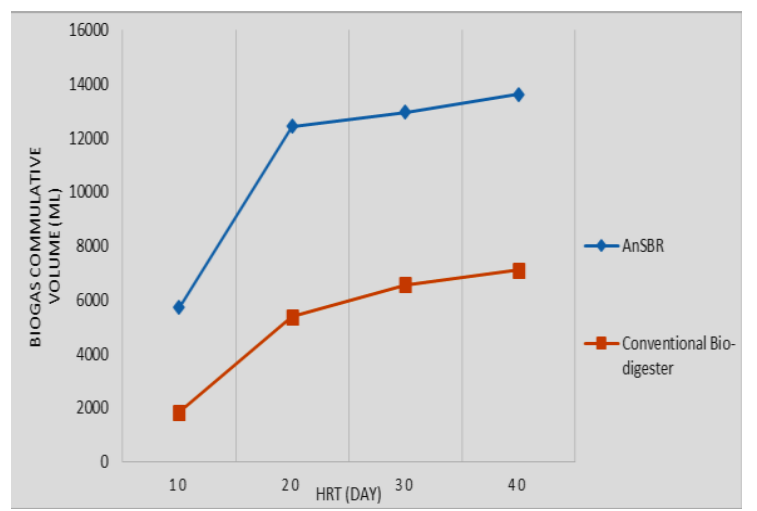

Fig. 2. The effect of HRT on biogas production.

\section{Conclusions}

Implementation of clean production that is integrated with waste water treatment does reduce the waste load to be treated in a treatment plant. This reduction in waste load reduces the cost for construction and operation of a treatment plan. At times, a waste water treatment plant's capacity to treat waste water is compromised by, among others: lack of fund, land acreage, and technology. Implementation of clean production prior to treating waste water should be able to reduce the waste load to certain points that the inherent lacks of a treatment plant can be minimized.

Biogas on HRT 16 has a $\mathrm{CH}_{4}$ and $\mathrm{CO}_{2}$ content of $78.26 \%$ and $20.16 \%$, respectively. They were produced by an AnSBR reactor with a batch operation that includes filling, reaction, precipitation, decanting, and stabilization. On the other hand, the conventional biodigester yielded biogas with a composition of $72.16 \%$ $\mathrm{CH}_{4}$ and $18.12 \% \mathrm{CO}_{2}$. Therefore, biogas production efficiency for AnSBR reactor is 2.14 times greater than that of the conventional bio-digester.

\section{Acknowledgement}

The writers would like to thank all parties contributing to this research, especially DRPM and the tofu industry in Pesalakan, Adiwerna sub-district, Tegal regency.

\section{References}

1. Azimi, A. A. and Zamanzadeh, M... Int. J. Environ. Sci. Tech. I, 1, pp. 51-57 (2014) 
2. Balsam, J., Burke, D.A.2011. Dairy Waste Anaerobic Digestion Handbook, Environmental Energy Company, Hill Street Olympia, pp. 17-27 (2016)

3. Borja, Caudia ET, Magali C Carmarota, Bio. Tech. 81(1), pp. 61 - 69 (2008)

4. Carucci,G.,F.Carrasco,K.Trifoni,M.Majone, and M.Beccari. J. Environ. Eng. 131 7, pp. 1037-1045 (2015)

5. Demirer, G..N., and S. Chen, Jou. Chem. Tech. and Bio. 79, pp. 1381-1387 (2014)

6. El-Gohary, Fatma A., Hala M. El-Kamah, and Sabah A. Badr., Australian Jou. Basic and App. Sci., 2 (4), pp. $1345-1355$ (2008)

7. El-Sheikh, Mahmoud A., Hazem I. Saleh, Joeseph R. Flora, Mahmoud R. AbdEl-Ghany., Desalination. 276, pp. $253-259(2011)$

8. G. Nakla, A. Lugowski, J. Patel, Bio. Tech., 97, 1, pp. 1-14 (2011)

9. Henze, M. and Ledin A. Types, Characteristics and Quanities of Classic Combined Wastewaters ,in P.
Lens. G. Zeeman, G Lettinga. Decentralized Sanitation and Reuse, IWA Publishing, UK., pp. 57-72 (2012)

10. M. Merzouki, N Bernet, JP Delgenes, Bio. Tech. 96, 12, pp. $1317-1322$ (2005)

11. Parawira,W., J.S.Read,B. Mattiasson, and L. Bjornsson, Bio.and Bio., 32, pp. 44-50 (2013)

12. Purwanto, Penerapan Teknologi Produksi Bersih untuk Meningkatkan Efisiensi dan Mencegah Pencemaran Industri, Universitas Diponegoro pub. (2009)

13. Rajeshwari, K.V., M.Balakrishnan, A. Kansal, K. Lata, and V.V.N.Kishore, Ren. and Sus. En. Rev., 2, pp. 135-156 (2013)

14. Sarapatka,B., Bio. and Bio., 5, 5, pp.387-393 (2013)

15. Syafila, Mindriany, A. H. Djajadiningrat, and $M$. Handajani, PROC. ITB Sains \& Tek., 35 A, 1, pp. 1931 (2003)

16. Yasar, Abdullah, and Tabinda, A. Bari, Polish J. of Env. Study 19, 5, pp.1051-1061 (2010) 